\title{
W STRONĘ LOKACYJNEGO MONOLOGU WYPOWIEDZIANEGO. O EKSPLOROWANIU LITERACKICH UCIELEŚNIONYCH PRZESTRZENI PAMIĘCI
}

\author{
Exploration of Embedded Literary Memory Spaces. On Locative Dramatic Monologue
}

\begin{abstract}
This paper offers a close reading of site-specific audio installation Data Urns (by Daniel Huber) and audio-walk Her Long Black Hair (by Janet Cardiff) in context of works created as corporeal and haptic experiences in different media. Used methodology is inspired by a new media and theatrical research as well as the traditional literary studies. Author uses category of dramatic monologue as a key to analyse literary aspects of characterized works and proposes the category of locative dramatic monologue as more useful in context of not-only-verbal immersive narratives. The goal of analysis (in which the category of haptic and exploratory reading is developed) can be also described as looking for possibilities of readapting traditional analytic tools in new (media) contexts as a way of postulated renewing of poetic of literary work.
\end{abstract}

Keywords: Data Urns, Daniel Huber, Her Long Black Hair, Janet Cardiff, dramatic monologue, literary locative narrative, szenische Erzählung, immersive literature, gestualized reading, haptic reading

\section{(Kolejne) odświeżanie zastanych narzędzi}

W 2018 roku Jordan Tannahill, jeden z najbardziej nagradzanych młodych kanadyjskich dramaturgów (najmłodszy w historii laureat Governor General's Literary Award, dwukrotny zreszta), wtedy trzydziestoletni, zadebiutował jako prozaik powieścią Liminal. Autofikcja ta, od razu postawiona przez krytyków w jednym rzędzie z Moją walka Karla Knausgarda, ma charakter rozliczeniowy nie tylko jako powieść gejowska, lecz również jako tekst ukazujący doświadczenie odchodzenia chorej na raka matki. Przejmująca pierwszoosobowa narracja Jordana, bohatera o wyraźnie autobiograficznej proweniencji, dogłębnie dokumentuje to osobiste doświadczenie liminalne, przekonująco 
i bez pardonu wrzucając czytelnika w plątaninę towarzyszących takiej sytuacji emocji. Prowadzony słowem, bezcieleśnie przenosi się on do utkanego ze wspomnień bohatera wirtualnego świata opowieści. Niezwykle silnie wybrzmiewa w kontekście tej prozy, właśnie ze względu na jej autobiograficzny charakter, diagnoza Anny Krajewskiej, twierdzącej, iż „performatywność literatury to przede wszystkim ustanawianie świata, w którym realność i fikcyjność pozostają w stanie splątania"1.

Jednak poprzedzający tę powieść, mający premierę na Biennale w Wenecji w 2017 roku, związany z nią teatralny performans VR Draw Me Close w reżyserii autora ,splątuje" realność i fikcyjność w sposób dużo bardziej przewrotny. Ta sama historia (czy jej część, bo choć dla powieści umieranie matki stanowi ramę, niekoniecznie jest jedynym jej tematem) opowiedziana jest tu również w pierwszoosobowej narracji, tym razem jednak raczej z perspektywy matki (co każe czytać te prace jako fascynujący dyptyk). Głosem przewodnim doświadczenia, słyszalnym jako dźwięk towarzyszący projekcji VR, jest monolog Jordana, który wprowadza poszczególne sekwencje wspomnień. W każdej scenie szybko ustępuje on jednak miejsca wypowiedziom wcielającej się $\mathrm{w}$ rolę matki aktorki, kierowanym do zaangażowanego $\mathrm{w}$ interakcję $\mathrm{z}$ nią widza. Ten ostatni, uzbrojony w gogle VR, widzi jedynie schematyczny biało-czarny świat, ewidentnie fikcyjny, wykreowany, sztuczny, co podkreśla wykorzystana konwencja filmowa (obraz odtwarza przestrzeń stanowiącą tło przywoływanych wspomnień2). Zaprojektowana sytuacja odbioru sprzyja oczywiście temu, by widz tego jednoosobowego spektaklu wszedł w rolę syna, by stał się podmiotem doświadczającym przywoływanych wspomnień. Jego percepcja jest ograniczona (ma wyłączony zmysł wzroku, wizję zastępuje tu projekcja w goglach), lecz tylko częściowo, dzięki czemu wrażenia z VR wzmocnione są tymi $\mathrm{z}$ otoczenia. Odtwarzająca rolę matki aktorka, rozmawiając z widzem, dotyka go (np. przytula, układa na łóżku i otula kocem). Wchodzi z nim w rozmaite interakcje, których efekty widz odbiera swoimi zmysłami (np. właśnie przez dotyk), a skutki widzi w wirtualnym świecie (nie tylko w sytuacji, gdy matka komentuje przytulenie, ale też np. kiedy wspólnie z widzem rysuje, a on widzi ten rysunek, zmieniający się w czasie rzeczywistym, w projekcji).

Choć w szkicu tym nie będę się skupiać na żadnej z przywołanych prac, ich zestawienie wydaje się idealnym wstępem do tych rozważań. Interesować mnie będą (około)literackie teksty, których - jak Draw Me Close - doświadczać możemy całym ciałem i w konkretnej przestrzeni. Chciałabym przyjrzeć im się jednak w perspektywie klasycznych strategii budowania literackiej immersji, równie efektywnych (czego dowodzi Liminal). Szukając kontekstów do badania dzieł e-literackich (oraz liberackich), w których lekturę angażowano gesty i ciało odbiorcy, coraz częściej trafiałam na inspirujące konteksty teatralne (w taki sposób poznałam spektakl Tannahilla). Badawcza intuicja wyraźnie podpowiadała, że nie da się mówić o VR w literaturze, nie badając jego

A. Krajewska, Humanistyka performatywna, „Przestrzenie Teorii” 2018, nr 29, s. 58.

Niezwykle ważne są w niej momenty ewoluowania jednej scenerii w drugą, szybkie przeskoki czasowe, komentowane też przez Jordana w jego narracji. 
wykorzystań w innych obszarach: w filmie, w sztuce interaktywnej, czy jak się później okazało - w teatrze (opowieściach niejako, ,spowinowaconych przez fabulę”’3). Zachęcał do tego fakt, iż coraz częściej pojawiały się VR-owskie rozwinięcia, prze-pisania i trawestacje tekstów oryginalnie realizowanych w innych mediach. Dotyczyło to również tekstów literackich - mam tu na myśli nie tylko adaptacje klasycznej literatury w VR ${ }^{4}$, lecz i VR-owskie prze-pisania e-literackich opowieści (np. Queerskins). Nierzadko też (niech przykładem będzie tu Queerskins: A Love Story) proponowano odbiorcom wręcz całe środowiska do doświadczania (środowiska XR czy MR), w których realność i wirtualność łączyły się w jedno, zaś podstawą doświadczania pracy było cielesne zanurzenie odbiorcy, zdecydowanie bardziej dosłowne niż w przypadku klasycznych werbalnych narracji wejście w wirtualny świat opowieści.

Spektakl Tannahilla (widziany w kontekście Liminal) uświadomił mi, że choć odmienność i niesamowitość doświadczenia, jakie oferuje, bazuje na niezwykłym wpleceniu cielesności podmiotu doświadczającego w akt odbioru dzieła, jedną z głównych wykorzystanych technologii (owszem, obok VR) pozostaje w nim słowo, (współ)odpowiedzialne za kreowanie immersji. Formułowana w tym szkicu propozycja metodologiczna zrodziła się zaś z wielu frustracji, w które popadałam, odkrywając, że teoretycy nowych mediów, teatru i literatury analizują te same (!) teksty (które inaczej kwalifikują gatunkowo), stosując skrajnie odmienne narzędzia (i nie mając zupełnie świadomości, że to robią, bo inaczej - wchodziliby przecież w dialog). Artykuł ten jest zatem pewnego rodzaju rozliczeniem nie tylko z badań (w zależności od kontekstu - mniej lub bardziej zaawansowanych) literackich narracji lokacyjnych, strategii angażowania cielesności czytelnika w proces lektury czy wykorzystania technologii VR w literaturze, lecz i z nieustannie towarzyszących tym badaniom problemów metodologicznych, wynikających najczęściej z rozmaitych nieścisłości.

O ile podkreśla się, jak ważne dla kreowania doświadczeń VR są wnioski wyciągnięte z działań o charakterze performatywnym (teatru postdramatycznego, partycypacyjnego, immersyjnego $)^{5}$, o relacji literatury i VR nadal mówi się raczej wyłącznie metaforycznie (lub - ze względu na kategorię interaktywności - w kontekście gier) ${ }^{6}$. Nie bada się użyteczności konkretnych form narracyjnych dla kreowania bazującej

J. Ziomek, Powinowactwa literatury: studia i szkice, PWN, Warszawa 1980.

4 Zarówno typowe cinematic VR (np. The Great C Steve'a Millera na podstawie opowiadania Philipa K. Dicka), jak i całe tzw. doświadczenia VR, np. korzystająca z kontrolerów ruchu VRtualna przemiana Miki Johnsona, swoiście adaptująca początek Kafkowskiej narracji i pozwalająca przeżyć przemianę w karalucha.

5 Por. m.in.: M. Reaney, Virtual Reality and the Theatre: Immersion in Virtual Worlds, „Digital Creativity” 1999, vol. 10, nr 3; S. Dixon, A History of Virtual Reality in Performance, „International Journal of Performance Arts and Digital Media" 2006, vol. 2, nr 1. Zob. też J.H. Murray, Hamlet on the Holodeck: The Future of Narrative in Cyberspace. Updated Edition, The MIT Press, London 2016.

6 Por. zwłaszcza M.-L. Ryan, Narrative as Virtual Reality: Immersion and Interactivity in Literature and Electronic Media, The Johns Hopkins University Press, Baltimore-London 2001; eadem, Narrative as Virtual Reality 2: Revisiting Immersion and Interactivity in Literature and Electronic Media, The Johns Hopkins University Press, Baltimore 2015. 
nie tylko na magii słowa immersji. Ja zaś chciałabym przyjrzeć się jej w szerszym nawet kontekście - nie tylko VR-owych, lecz i ucieleśnionych, zmaterializowanych fikcyjnych światów do eksplorowania. Sądzę, że aby je badać, należy poszukiwać nie tyle nowych narzędzi i metodologii, co możliwości odświeżenia tych istniejących. Sugeruję sprawdzenie ich użyteczności w nowym kontekście. Niniejszy tekst to próba pokazania, jak można w celu badania tekstów immersyjnych z wyraźnym werbalnym komponentem użyć bardzo tradycyjnych teoretycznoliterackich kategorii, którym przyglądam się jednak z nieco innej perspektywy, wpisując się w postulowane od lat projekty odświeżania poetyki w kontekście e-literackości.

Jednak o ile w przypadku prób formułowania metodologii lektury tekstów umownie powiedzmy - ,haptycznych” (zwłaszcza tych pisanych na ekrany dotykowe, tzw. small screen fiction ${ }^{7}$ ) można powiedzieć, że wskazano kierunek, w jakim należy poszukiwać, określono, jak odświeżać poetykę, by dostosować jej narzędzia do aktualnego pejzażu literackiego (pisali o tym m.in.: Serge Bouchardon, Diogo Alexandre da Silva Marques, Ewa Szczęsna ${ }^{8}$ ), o tyle, kiedy mowa o angażowaniu w proces lektury całego ciała odbiorcy, proces takiej metodologicznej ewolucji jest jeszcze w toku. A przecież ta, uwzględniająca figury czytelniczych gestów, poetyka wpisuje się w bardziej pojemny model nowej hermeneutyki, której sformułowanie wiele lat temu postulował Roberto Simanowski w kontekście „całocielesnego” właśnie doświadczania nowomedialnych instalacji (literackich!), nie zaś wyłącznie ich dotykania9. Zatem to nie pojawienie się ekranów dotykowych i - co za tym idzie formuły tzw. czytania tabletowego oraz tekstów, które są w równym stopniu „czytalne” (readable), co „dotykalne” (touchable) ${ }^{10}$, podyktowało potrzebę odświeżenia

Choć warto pamiętać, że czytelnicze gesty jako projektowaną strategię lekturową wykorzystywano już wcześniej, zanim pojawiły się ekrany dotykowe. Ikoniczna wydaje się tu ewolucja dostrzegalna w twórczości Serge'a Bouchardona, będącego nie tylko jednym z czołowych teoretyków haptycznej poetyki, ale i autorem kanonicznych reprezentatywnych dla niej tekstów. Toucher (2009) eksplorował figury czytelniczych gestów zapośredniczone przez tradycyjny interfejs PC, myszkę (ale podkreślę, że utwór ten wykorzystywał też szerzej rozumianą cielesność odbiorcy: np. śledził jego oddech czy wzrok); Loss of Grasp od 2010 roku dostępne jest online, w 2018 roku miało powtórną premierę, już w formie aplikacji na ekrany mobilne (pol. (Nie)panowanie, podobnie jak kilka innych wersji językowych utworu, nadal dostępne jest wyłącznie w tej pierwszej wersji), zaś Do It (2016) funkcjonuje już wyłącznie jako tekst „dotykalny”.

$8 \quad$ Zob. m.in.: S. Bouchardon, Figures of Gestural Manipulation in Digital Fictions, w: Analyzing Digital Fiction, eds. A. Bell, A. Ensslin, H.K. Rustad, Routledge, New York 2014; D. Marques, Reading Digits: Haptic Reading Processes in the Experience of Digital Literary Works, Coimbra 2018, praca doktorska opublikowana online: https://estudogeral.sib.uc.pt/handle/10316/81171 (dostęp: 10.01.2020); E. Szczęsna, Cyfrowa semiopoetyka, IBL PAN, Warszawa 2018.

9 R. Simanowski, What Is and to What End Do We Read Digital Literature?, w: Literary Art in Digital Performance: Case Studies in New Media Art and Criticism, ed. F.J. Ricardo, Continuum, New YorkLondon 2009, http://dm.postmediumcritique.org/Book_LiteraryArtInDigitalPerformance.pdf (dostęp: 28.05.2013).

10 C.A. Milligan, The Page Is a Touchscreen: Haptic Narratives and “Novel” Media, „Paradoxa” 2017, nr 29 (Small Screen Fictions, eds. A. Ensslin, L. Swanstrom, P. Frelik), s. 287. 
metodologii (choć nie da się zaprzeczyć, iż - jak podkreślała choćby Anastasia Salter ${ }^{11}$ - wprowadzenie iPada zrewolucjonizowało e-literaturę i e-czytanie). Szkic ten będzie się zatem skupiać na analizach nie tyle „czytania gestycznego”12, którego teorię konsekwentnie buduje Bouchardon, ile takiego, które - zapożyczając się $\mathrm{w}$ rozważaniach o roli ciała $\mathrm{w}$ teatrze immersyjnym prowadzonych przez Josephine Machon - można by określić „,haptycznym”"13, takim, w którym całe „,iało czytelnika zastępuje jego oko"14, jak ujęła to Amaranth Borsuk ${ }^{15}$. Proponowane ujęcie można traktować też jako rozwinięcie koncepcji „czytania eksploracyjnego”, przedstawionej przez Stephanie Strickland i Cynthię Lawson ${ }^{16}$.

Choć nie roszczę sobie prawa do nadawania formułowanym na tym etapie badań przeczuciom rangi ostatecznych wniosków, staram się zaproponować pewną metodologię czytania tekstów, z jakimi przez ostatnie lata wielokrotnie się mierzyłam: tekstów, które mimo wyraźnego werbalnego komponentu są co najwyżej quasi-literatura, ale za to taką, która nieco bardziej dosłownie pozwala wchodzić w swoje wirtualne światy ${ }^{17}$. Z tej perspektywy przyjrzę się tu przede wszystkim dwóm utworom, kreującym wirtualne przestrzenie pamięci: instalacji Data Urns Daniela Hubera oraz audio-walkowi Her Long Black Hair Janet Cardiff. Wskażę, w jak dużym stopniu oferowane przez nie immersyjne doświadczenia bazują na klasycznej werbalnej narracji i jak jej ukształtowanie wpływa na możliwość wykorzystania potencjału cielesnej immersji. Kluczowym punktem odniesienia będzie tu dla mnie konstrukcja narracji uwzględniającej, bądź nie, kategorię słuchacza, zwłaszcza teoria monologu wypowiedzianego. W zakończeniu, przywołując kolejne prace, pokrótce zasygnalizuję, jak dla podobnych analiz można by przepracować kategorię opowiadania scenicznego. Na koniec wypada dodać, iż

11 A. Salter, What Is Your Quest? From Adventure Games to Interactive Books, University of Iowa Press, Iowa City 2014.

12 S. Bouchardon, Mind the Gap! 10 Gaps for Digital Literature?, „Electronic Book Review” 2019, May 5, http://electronicbookreview.com/essay/mind-the-gap-10-gaps-for-digital-literature/ (dostęp: 1.06.2019).

13 J. Machon, Immersive Theatres. Intimacy and Immediacy in Contemporary Performance, Palgrave Macmillan, London 2013, s. 283.

14 A. Borsuk, The Book, The MIT Press, Cambridge 2019, s. 156.

15 Choć pozostanę w kręgu odświeżeń i rewizji, których potrzeba wydaje się konsekwencją twórczego wzajemnego wpływania na siebie literackich form elektronicznych i analogowych (por. S. Bouchardon, D. Heckman, Digital Manipulability and Digital Literature, „Electronic Book Review” 2012, August 5, https://electronicbookreview.com/essay/digital-manipulability-and-digital-literature/ (dostęp: 1.02.2020).

16 S. Strickland, C. Lawson, Vniverse, w: New Media Poetics: Contexts, Technotexts, and Theories, eds. A. Morris, T. Swiss, The MIT Press, Cambridge 2006, s. 177. Por. też A. Przybyszewska, Po(d)żeranie tekstu. Wstęp do rozważań o czytaniu kinetycznym, e-polonistyka 3, red. A. Dziak, A. Kopacz, Wydawnictwo KUL, Lublin 2016.

17 Warto tu pamiętać o tym, że pragnienie umieszczania widza wewnątrz obrazu i świata fikcyjnego widoczne jest obecnie w różnego rodzaju praktykach kulturowych: dość przypomnieć paryskie L'Atelier des Lumières czy inicjatywy w rodzaju Secret Cinema. 
choć w szkicu tym ograniczam się do utworów zanurzających w przeszłość, wpisujących się w praktyki ucieleśniania pamięci, formułowane tu wnioski można, jak sądzę, traktować jako bardziej ogólne.

\section{Nieistotny świadek, kłóry w teraźniejszości podgląda przeszłość z przyszłości}

Data Urns Daniela Hubera to jeden z projektów, które złożyły się na wystawę Time Capsule - Narration for a Future, przygotowaną przez studentów wydziału komunikacji wizualnej University of Arts and Design w Linzu w ramach festiwalu Ars Electronica w 2019 roku. Inspiracją dla poszczególnych prac stał się tzw. Voyager Golden Record, czyli dane dokumentujące w obrazach i dźwiękach Ziemię, przygotowane jako tytułowa kapsuła czasu dla misji kosmicznej NASA w 1977 roku. Istotą projektu Hubera było zwrócenie uwagi na to, co w przyszłości będzie dziać się z kolekcjonowanymi przez nas w formie danych wspomnieniami, postawienie pytań o granice tego, na ile cyfrowość pozwoli nam ,przetrwać po życiu”, przedłużać i symulować kontakt ze zmarłymi ${ }^{18}$. Praca wydaje się również krytyką obsesyjnego kolekcjonowania danych, rodzącego się z „poczucia, że nie istnieje spontaniczna pamięć”, że musimy budować i tworzyć, jak to określił badający tzw. „miejsca pamięci” Pierre

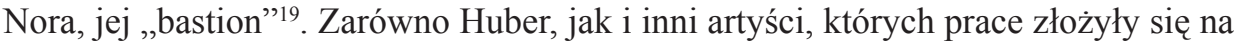
przywołaną wystawę, przepracowali twórczo ideę wiadomości wysłanej z przeszłości do nieznanych odbiorców w przyszłości, proponując kapsuły czasu rozumiane jako dające się dotknąć, zmysłowo poznawalne (ang. tangible) opowieści o przeszłości ${ }^{20}$.

W przypadku ascetycznej, lecz angażującej całe ciało i wiele zmysłów użytkownika, dźwiękowej instalacji site-specific Hubera owa namacalność stanowiła tylko jeden z elementów przesądzających o ostatecznym kształcie precyzyjnie zaprojektowanej sytuacji odbiorczej. Użytkownik Data Urns wkraczał w wyraźnie odgrodzoną przestrzeń: ustawione w centrum pomieszczenia cztery podesty-pulpity okalała dająca poczucie intymności półprzezroczysta zasłona, na której zawieszono symboliczny świetlisty podwójny krzyż (zob. ilustracja 1). Akt jej odsłonięcia stanowił swoisty pakt z „czytelnikiem”, symboliczne przekroczenie progu opowieści. Taka organizacja przestrzeni wzmaga odczucie intymności odbioru, wpływając istotnie na liczbę jednoczesnych odbiorców dzieła. Wzięcie do ręki jednej z trzech stojących

18 Nie brak też projektów, które te same pytania/wyzwania stawiają w stosunku do technologii bardziej immersyjnych (AR czy VR): przykładem Hacker Dead z cyklu 2081 Agi Szuścik (prezentowany na Festiwalu Sztuki Cyfrowej Patchlab w Krakowie w 2018 roku) czy Meeting You Kim Jong-woo; zob. https://www.reuters.com/article/us-southkorea-virtualreality-reunion/south-korean-mother-giventearful-vr-reunion-with-deceased-daughter-idUSKBN2081D6 (dostęp: 31.01.2020).

19 P. Nora, Między pamięcia i historia: Les lieux de Mémoire, w: Tytut Roboczy: Archiwum\#2, red. M. Ziółkowska, A. Leśniak, Muzeum Sztuki w Łodzi, Łódź 2009, s. 6.

$20 \mathrm{Z}$ opisu wystawy w katalogu Ars Electronica: https://ars.electronica.art/outofthebox/en/timecapsule (dostęp: 10.03.2020). 
na mniejszych podestach urn i ustawienie jej na dodatkowym, celowo większym niż pozostałe i prowokacyjnie pustym, uruchamiało audioopowieść, inną w przypadku każdej urny. Nagranie miało formę skierowanego do bliskiej osoby monologu zmarłego, osobistego listu pośmiertnego ${ }^{21}$.
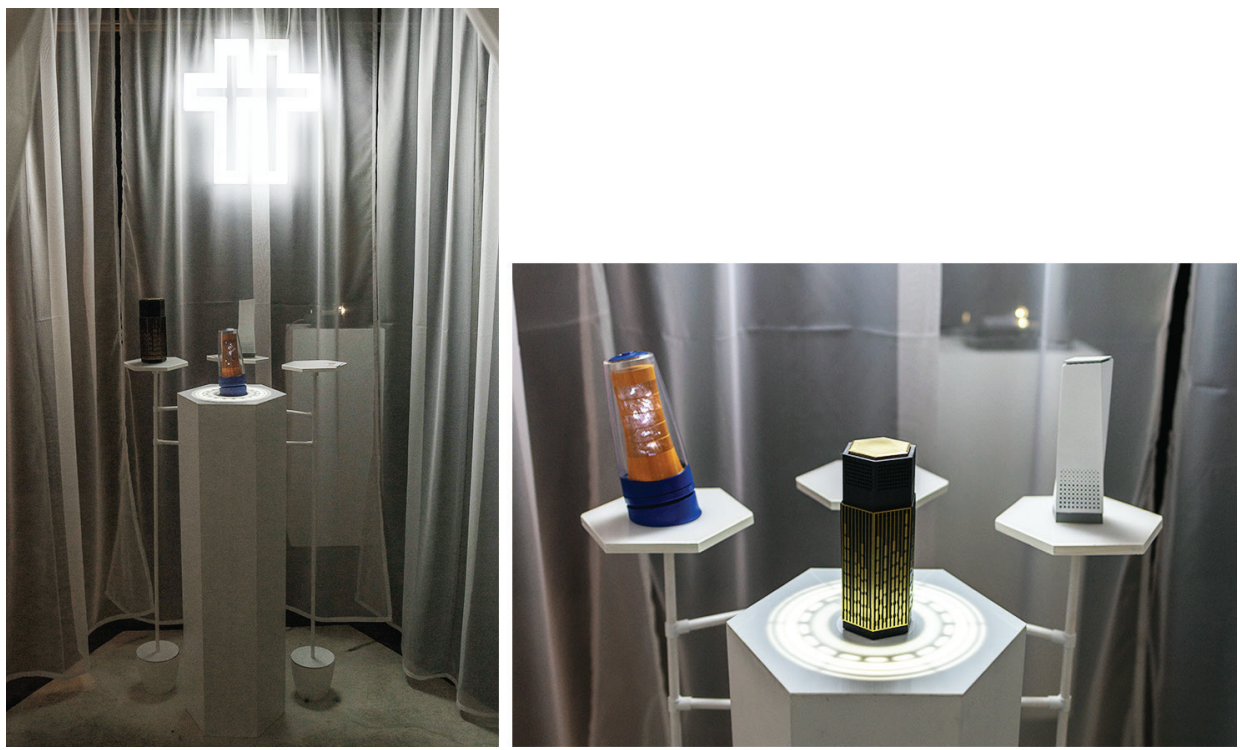

Il. 1. Daniel Huber, Data Urns

Uruchamiający projekcję gest odbiorcy, jego kontakt z urną z digitalnymi prochami (realnym, materialnym przedmiotem, należącym przecież jednak do świata fikcji) oraz sama przestrzeń odbioru (wykreowana tak, by ułatwić „,wślizgnięcie się” do innego świata) stanowiły istotne składowe misternie zaprojektowanej sytuacji odbiorczej. Jednak to słowo pozostawało głównym nośnikiem opowieści, która, choć jako klasyczne dzieło site-specific nie miałaby szansy wybrzmieć w pełni odbierana w innej przestrzeni, odarta ze słów - nie wybrzmiałaby w ogóle. Tym samym choć trudno powiedzieć, że Data Urns to utwór czysto literacki (choć liberacki już owszem $^{22}$ ), z pewnością można tu mówić o literackiej czy werbalnej dominancie.

21 Na formułę listu wskazywałyby rozpoczęcia i zakończenia tekstów: „Dear Louisa” / „Dear Dr. Lenz” czy „Loving you always and forever” / „Yours sincerely Kim Sander” (cytuję na podstawie udostępnionych przez autora skryptów).

22 Przypomnę, że dość tradycyjnie literacka, bo - zamknięta w kodeksie - liberatura grywała już z materialnością fikcyjnych przedmiotów. S. Jeffreya Jacoba Abramsa i Douga Dorsta przybrało przecież formę „opakowania” dla „prawdziwej” (choć będącej częścią fikcyjnego, wyobrażonego świata tej opowieści) książki Ship of Tezeus nieistniejącego pisarza Straki. Jego czytelnik dostaje więc do rąk prawdziwy falsyfikat rzeczywistości, liberackie symulakrum, realne ucieleśnienie tego, czego nie ma. 
W dalszych analizach poświęcę temu aspektowi pracy sporo uwagi, by pokazać, jak bardzo narracyjne (werbalne) ukształtowanie opowieści warunkuje jej immersyjność. Bo immersja kreowana jest tu równolegle przez językowe ukształtowanie narracji (bezpośrednie zwroty do odbiorcy, osobisty charakter samej opowieści, nawiązywanie kontaktu), jak i zaprojektowane środowisko jej doświadczania (intymną przestrzeń odgrodzoną od reszty świata, sakralno-mistyczny, symbolicznie liminalny charakter miejsca odbioru).

Zacznijmy od przewrotnej struktury czasowej proponowanego doświadczenia. Wysłuchujemy opowieści trojga zmarłych, przypominających i komentujących swoje życie, co - siłą rzeczy - winno przenosić nas w przeszłość. Tym samym skrupulatnie zaprojektowana przestrzeń tej instalacji wydaje się ,immersyjną przestrzenią pamięci”, a nawet (prywatnym) „miejscem pamięci” w rozumieniu Nory (ów intymny wymiar doświadczenia zdaje się wzmagać immersję). Zanurza nas w przepracowany świat wspomnień mówiących do nas zmyślonych postaci: Vincenta, Erica oraz Kim Sander. Jednocześnie te monologi ${ }^{23}$ wypowiadane są przecież z przyszłości - wszyscy troje zmarli bowiem w 2069 roku (zaś najmłodsza z przemawiających, Kim, z perspektywy słuchającego jeszcze nie przyszła na świat, gdyż urodziła się dopiero w 2042 roku). Odbiorca zanurza się więc aż w trzech płaszczyznach czasowych, doświadcza w swoim ,tu i teraz” zarówno bycia w przyszłości, jak i przeniesienia się w przeszłość. Przekracza to najczęstsze strategie wykorzystania poczucia teleobecności w obszarze praktyk związanych z przestrzeniami pamięci - te bazują zwykle na przeniesieniu w inny czas (klasycznym przykładem są wystawy historyczne typu site-specific).

Proponowane przez Hubera doświadczenie pozwala odbiorcy nie tylko poczuć się w sytuacji człowieka z przyszłości, wcielić w rolę kogoś, kto dzięki rozwojowi technologii może otrzymać wiadomość od zmarłego. Jednocześnie słuchacz, sterowany słowami opowieści, przenosi się w przeszłość opowiadających, zanurza we wspólne dla nadawcy i zakładanego przezeń odbiorcy wspomnienia. Z jego perspektywy mogą one dotyczyć przeszłości lub przyszłości, lecz punktem odniesienia staje się dla niego przestrzeń czasowa podmiotu mówiącego. Trudno, by było inaczej, skoro struktura tekstu (a konkretnie - narracji) umiejscawia go w opowieści jako podglądacza (bo przecież nie wyłącznie podsłuchiwacza) życia bohaterów opowieści. Odbiorca Data Urns niekoniecznie bowiem wciela się w rolę adresata/ów listów z urn, choć narracja, której słucha, wykorzystuje formuły bezpośrednich zwrotów do adresata. Choć gest „skorzystania” z urny jest potencjalnym powtórzeniem działania postaci z fikcyjnego świata (adresata ukrytej w urnie wiadomości), trudno powiedzieć, by odbiorca pracy się z nią utożsamiał. By tak było, musiałby uznać za własny bagaż wspomnień stanowiących podstawę porozumienia między nadawcą wiadomo-

23 Adresowane odpowiednio do: partnerki, której Vincent pragnie zapewnić bezpieczne życie niezależnie od własnej śmierci, syna, z którym Eric w konsekwencji popełnionego przestępstwa nie miał kontaktu, choć śledził uważnie jego losy, oraz lekarza, którego badania nad chorobą, na którą umarła, chce wesprzeć Kim. 
ści z urny a jej założonym (nazywanym po imieniu) odbiorcą. A tego zrobić raczej nie może.

Użytkownik Data Urns, stojąc ,,we wnętrzu kaplicy”, owszem, wchodzi w wirtualne ciało czy też rolę (bo ciało nadal ma własne) kogoś, kto znajduje się wewnątrz fikcyjnego świata. Przyjmuje tym samym intradiegetyczny punkt widzenia, niczym literacki narrator personalny ${ }^{24}$. Jednak - głównie ze względu na językowe ukształtowanie opowieści - nie może do końca poczuć się pełnoprawnym mieszkańcem tego świata, jest tam raczej na zasadach podglądacza (choć niekoniecznie intruza) ${ }^{25}$. Taki efekt umiejscowienia niewidzialnego odbiorcy w świecie opowieści znany jest z kina VR (przykładem Limbo w reżyserii Shehani Fernando ${ }^{26}$, którego odbiorcy niemo towarzyszą szukającym azylu uchodźcom) czy teatru partycypacyjnego/immersyjnego (instalacjo-spektakli w rodzaju Sanctuary Bretta Baileya, którego uczestnicy zwiedzają labirynt ośmiu pomieszczeń, a każde kryje historię innego wygnańca ${ }^{27}$ ). Odbiorca staje w takich sytuacjach, dosłownie, twarzą w twarz ze światem opowieści,

24 Do tego, jak użyteczna może być w analizach interesujących mnie prac kategoria narracji personalnej czy też stojącej za nią prezentacji scenicznej, wrócę w końcowej części tego szkicu.

25 Literacki narrator nie ma takiego dyskomfortu, co wiąże się z faktem, że w przypadku przywołanej strategii narracyjnej nie jest postacią w świecie przedstawionym, a jego funkcją jest jedynie udostępnienie tego świata odbiorcom.

26 Ta nagradzana reżyserka doskonale wykorzystuje VR jako „maszynę empatii”, by poruszać problemy nie tylko polityczne, ale i czysto ludzkie. Jej Party pozwala doświadczyć urodzinowego przyjęcia z perspektywy szesnastoletniej jubilatki cierpiącej na autyzm, zaś autobiograficzne The Waiting Room $V R$ w reżyserii Victorii Mappbeck, którego była producentką (premiera na festiwalu w Wenecji w 2019 roku), pozwala wcielić się w rolę towarzysza ostatniej sesji radioterapii chorej. Oba te projekty zakładająjednak inną niż w Limbo rolę widza, stąd byłyby lepszym punktem odniesienia dla dalszej części tego szkicu, gdzie właśnie o takiej strategii będzie mowa. Druga ze wspomnianych prac wpisuje się też w wyraźnie dostrzeganą tendencję tworzenia doświadczeń VR jako towarzyszących tekstom oryginalnie realizowanym w innych mediach, rozwijających je lub traktujących jakąś część z pierwotnej fabuły jako bazę (w zakresie filmów, które doczekały się takiego rozwinięcia w VR, narzuca się tu jako analogiczny przykład Manic VR Kaliny Bertin, nagrodzony Golden Nica na Ars Electronica w 2019 roku, w obszarze teatru i VR - wspomniany spektakl Tannahilla, ze świata e-literackich prze-pisań: Queerskins Illyi Szilak).

27 Moc oddziaływania wzmaga tu również fakt, że aktorami są rzeczywiście imigranci i uchodźcy oraz aktywiści. W tym jednak wypadku trzeba zaznaczyć, że ci, którzy pełnoprawnie „zamieszkują” świat przedstawiony, widzą odbiorców, zdają sobie sprawę z ich obecności i artystycznie przepracowują napięcie z tego płynące. Nie mam tu na myśli logicznej różnicy między mediami (trudno, żeby bohater nieinteraktywnego filmu VR zobaczył widza), lecz fakt, że aktorzy celowo nie wchodzą z uczestnikami spektaklu w interakcję, nie zapraszają ich do swojego świata. „Milczą, ale patrzą” - podsumował Christophe Candoni w recenzji na łamach „Toute La Culture” (C. Candoni, Sanctuary, Brett Bailey du côté des réfugiés, 19.06.2017, https://toutelaculture.com/spectacles/sanctuary-brett-bailey-du-cotedes-refugies/ [dostęp: 10.01.2020]). Można by powiedzieć, że natrętnie i manifestacyjnie patrząc - nie widzą: dostrzegają widzów, nieraz wymownie się w nich wpatrują lecz z premedytacją nie nawiązują kontaktu, podkreślając granice dzielące te dwa światy. Strategię tę i jej cel dobrze podsumowuje deklaracja jednego z uchodźców wypisana na kartonie (słowo w takiej właśnie formie, napisów w obrębie przestrzeni doświadczenia, odgrywa w tym spektaklu ogromną rolę): „Je te vois qui ne me vois pas” („Widzę was, którzy mnie nie widzicie”). 
konfrontuje się z sytuacją, w którą uwikłani są jej bohaterowie ${ }^{28}$. W czysto literackiej narracji postrzega wtedy jedynie świat performatywnie stwarzany przez słowo w wyobraźni czytelnika, a w VR - jego trójwymiarową iluzję, dynamicznie zmieniającą się w czasie rzeczywistym, zastępującą chwilowo prawdziwą percepcję. W przypadku performansów i instalacji (zatem i Data Urns) konfrontuje się jednak bezpośrednio z fikcyjnym światem: ucieleśnionym, widzialnym, namacalnym i słyszalnym, dostępnym do prawdziwej eksploracji, co zasadniczo zmienia jakość doświadczenia (doświadczenia, które istotnie ucieleśnia marzenia o „prawdziwej” immersji). „Twarzą w twarz, oko w oko - w tej sytuacji niemożliwe jest zostać obojętnym" - pisał o Sanctuary na łamach „Toute La Culture” Christophe Candoni ${ }^{29}$, podkreślając siłę oddziaływania tego typu sztuki. Z niej właśnie korzysta Data Urns. Nie ocenia, nie narzuca - stawia świat przedstawiony przed odbiorca, pozwalając mu samemu po prostu czuć i wyciagać wnioski.

Huber, podobnie jak przywołani twórcy, nie pogłębia tego wrażenia, nie zakłada, że odbiorca mógłby być kimś więcej niż świadkiem. Zanurza go w świat, pozwala mu nawet działać w jego obrębie (zważywszy na to, że jego gest uruchamia samą pracę - wręcz wymaga tego od odbiorcy), nie czyni jednak tego świata prawdziwie jego. A wszystko - przez wybraną formę narracji. Przyjrzyjmy się pod tym kątem monologowi Erica zwracającego się do syna, który go nie zna. To wypowiedź, która pozornie najbardziej sprzyjałaby utożsamieniu się użytkownika $\mathrm{z}$ jednym $\mathrm{z}$ bohaterów, pozwalając mu tym samym rzeczywiście stać się częścią opowieści. Wiedza założonego odbiorcy wiadomości i wpisanego w tekst adresata wypowiedzi są w tym wypadku zrównane, pozornie tożsama jest więc też ich sytuacja i emocje, jakich dostarcza. Tym samym - teoretycznie - słuchacz nieco łatwiej mógłby się odnaleźć wewnątrz fikcyjnego (zmaterializowanego) świata. Jednak takie utożsamienie się nie jest w pełni komfortowe, gdyż zbyt silnie narzuca się odbiorcy wyraźnie wykreowaną jego własną (lecz cudzą) historię (podobnie mało „wygodne” wydają się drugoosobowe narracje Aury Carlosa Fuentesa czy Przemiany Michela Butora ${ }^{30}$, zwłaszcza gdy przyjrzymy się im w kontekście nowszych, też interaktywnych - choć nie zawsze nowomedialnych - realizacji tej formy, np. Jetlagu Michała Wiśniewskiego). Dodatkowo osobisty ton wypowiedzi może też krępować odbiorcę (z takim napięciem, towarzyszącym byciu świadkiem intymnego wyznania, mamy często do

28 Baileyowi na przykład - jak wyjaśniał w jednym z wywiadów - chodziło właśnie o wpisujące się w założenia teatru partycypacyjnego sprowokowanie widzów do refleksji poprzez konfrontację z szokująca, silnie oddziałującą na emocje sceną (traktowaną - dodam - raczej jako współczesna realizacja koncepcji żywych obrazów niż część klasycznego spektaklu).

29 C. Candoni, op. cit.

30 Owo napięcie słusznie podsumowuje Magdalena Rembowska-Płuciennik, określając ramę semantyczną narracji drugoosobowej za pomocą następującej struktury: „opowiadam ci, jak to jest być tobą w tej właśnie niepowtarzalnej sytuacji”. M. Rembowska-Płuciennik, O przechodzeniu na ty... Narracja diadyczna wśród literackich reprezentacji świadomości bohatera, w: (W) sieci modernizmu. Historia literatury - poetyka - krytyka. Prace ofiarowane Włodzimierzowi Boleckiemu, red. A. Kluba, M. Rembowska-Płuciennik, IBL PAN, Warszawa 2017, s. 255. 
czynienia w narracji pierwszoosobowej, zwłaszcza jeśli przyjmuje ona - oczywistą tu jako kontekst - formułę powieści epistolarnej ${ }^{31}$ ).

I have missed most of your birthdays, but please look upon this as a gift - wyznaje Eric. - You don't even have to open it, but I wish to leave you some of my memories, experiences, and insights. I leave you my complete social network, a number of valuable people, who might be able to help you once you finish college [...] All in all, there are 1.2 million snapshots in form of imagery, audio, video and photography, of me, y countless travels and my two faithful dogs. These records will hopefully enable you to have a sort of memory of me, your father ${ }^{32}$.

Słuchając tych słów wewnątrz symbolicznej kaplicy, można rzeczywiście poczuć się jak ktoś, komu właśnie „sprezentowano” cały komplet, chwilę temu jeszcze dla niego nieistniejących, wspomnień. W innych fragmentach monologu wiele jednak szczegółów wybijających z takiej immersji, burzących potencjalne utożsamienie: choćby imię prawdziwego odbiorcy czy informacja o tym, że zostanie ojcem ${ }^{33}$. Co więcej - to te właśnie „drobiazgi” stanowią z kolei fundament intymnego wymiaru tej „spowiedzi”. Pozostałe dwa monologi nie zostawiają (na poziomie samej kreacji ich odbiorców) w ogóle takich potencjalnych ,furtek” do wchodzenia w rolę odbiorców (choć można by się zastanowić, czy wyraźnie dostrzegalna różnorodność nadawców i odbiorców nie miała na celu także „dywersyfikacji” oferowanych postaci do utożsamienia się).

Immersyjność tej historii bazuje na specyficznym ukształtowaniu narracji, której moc wzmaga możliwość bycia i działania w przestrzeni materializującej fikcyjną

31 Oczywiście to napięcie jest w takim wypadku najczęściej artystycznie przepracowywane, dość przypomnieć nagrodzone Nagrodą Bookera Białe na czarnym Rubéna Gallego, czysto literacki przykład tworzenia immersyjnej przestrzeni pamięci. W tej poruszającej do bólu pierwszoosobowej narracji autor, quasi-sierota wychowana w sowieckich domach dziecka, opisując z dystansu swoje życie, sięga po formę krótkich rozdziałów-impresji, często charakteryzowanych przez krytyków jako „filmowe sekwencje". Dający się porównać z - także ewidentnie filmową, niczym kamera wyłuskującą z całokształtu najdrobniejsze detale, z których buduje potem przekonujący obraz całości - narracją Paola Sorrentino z Nieistotnych wizerunków, tekst ten wskazywałby kolejny, przekraczający ramy tego szkicu, kontekst badań: problem subiektywizacji narracji i fokalizacji, przepracowywany na różnych płaszczyznach medialnych (dość przywołać tu kategorie: współfokalizacji, opisywanej jako „punkt działania”, a nie „widzenia” w groznawstwie, czy „subiektywizacji zapośredniczonej” w rozważaniach filmoznawczych - teorii rozwijanej przez Roberta Birkholca w książce pod znamiennym tytułem Podwójna perspektywa).

32 „Nie było mnie na większości Twoich urodzin. Jednak, proszę, popatrz na to [nasze spotkanie A.P.] jak na prezent. Nie musisz go nawet otwierać, ale chciałbym zostawić Ci trochę moich wspomnień, doświadczeń, przemyśleń. Zostawiam Ci wszystkie moje kontakty, to namiary na wielu wartościowych ludzi, niektórzy może będą mogli Ci pomóc, kiedy skończysz szkołę [...] Koniec końców to 1,2 miliona migawek w formie obrazów, zdjęć, fotografii, na których utrwalono obraz mnie, moich dwóch wspaniałych psów czy niezliczonych podróży. Liczę, że te wspomnienia pozwolą Ci mieć jakieś wspomnienie czy wyobrażenie mnie, Twojego ojca”. (Cytuję ze skryptu udostępnionego przez autora - tłumaczenie A.P.).

33 Ten sam problem dostrzec można we wspomnianych narracjach Fuentesa czy Butora. Pakt z czytelnikiem zakłada w tych wypadkach zgodę na taki czytelniczo-egzystencjalny dyskomfort. 
sytuację odbiorczą, w której, zgodnie z logiką opowieści, można uczestniczyć. Zakłada się zatem, że odbiorca będzie zarazem dosłownie, jak i tele-obecny w zmaterializowanym przed nim świecie fikcji, jednak nie przypisuje się mu w nim żadnej wyraźnej roli. Niczym uczestnicy przywoływanych spektakli teatru partycypacyjnego czy kina VR aktywnie podgląda on ten świat (interpretuje, ocenia, przeżywa), nie ma jednak możliwości nań oddziałać, bo z perspektywy jego mieszkańców jest niezauważalny. To niemy świadek, dla którego nie przewidziano żadnej roli w świecie opowieści. W perspektywie rozmaitych form narracji interaktywnych (filmowych czy grywalnych, ale przecież i literackich, niekoniecznie wyłącznie nowomedialnych ${ }^{34}$ ) zaproponowana przez Hubera opowieść wydaje się więc zarazem innowacyjna i zachowawcza. Wkracza na fascynująca ścieżkę immersyjności wzmocnionej zaangażowaniem ciała i gestów odbiorcy, jednak w gruncie rzeczy nie robi zeń większego użytku (nie pozwala tym działaniom odbiorców współtworzyć sensu opowieści). Nie czynię z tego zarzutu (uważam, że praca w bardzo ciekawy sposób konfrontuje odbiorcę z poruszanym przez nią problemem, wejście do jej wnętrza było też inspirującym doświadczeniem), intryguje mnie tylko, jak pójść krok dalej.

W przypadku wspomnianego Manic VR Kaliny Bertin ${ }^{35}$ pierwszoosobowa narracja (też w formie listów!) oraz obraz projekcji VR pozwalały odbiorcy doświadczyć kolejnych faz choroby dwubiegunowej, poczuć to, o czym opowiadają autorzy wiadomości (rodzeństwo autorki tego autobiograficznego projektu). Ponieważ stan, o którym mówią i którego tak się boją, powraca cyklicznie, ich opowieść - przenosząca nas w świat zbudowany ze wspomnień - również dałaby się interpretować jako „immersyjna przestrzeń pamięci”, choć mocno bazuje na poczuciu teraźniejszości. Pozornie w Manic VR też mamy do czynienia z sytuacją zaprojektowanego podsłuchiwania/podglądania czyjejś korespondencji - każdy z listów rozpoczynał się bezpośrednim zwrotem nie do nas, lecz do Kaliny (np.: „Hi Kalina... it’s me. I think it has started again”). Charakter doświadczenia warunkowało tu jednak silniejsze niż w Data Urns wykorzystanie interakcji. Jej umożliwienie (a później odebranie) w każdej z kolejnych scen ilustrowało treść opisujących kolejne stadia choroby wiadomości. Sposób obrazowania wiązał się z tym, jak kolejne stadia choroby przekładają się na sposób widzenia świata (co potwierdzone jest badaniami). W konsekwencji - choć listy Felicii i François są werbalnym motywem przewodnim

34 Obok typowych nowomedialnych publikacji w rodzaju Maginary (Semyon Polyakovskiy), Pry (Samantha Gorman, Danny Cannizzaro) czy bardziej klasycznych literackich hipertekstów - można tu przywołać również powieści paragrafowe czy interaktywne igraszki Sterne'a z Życia i myśli J.W. Pana Tristrama Shandy (gdzie np. czytelnik ma sobie namalować portret bohaterki).

35 Przypomnę, że to doświadczenie VR poprzedził zrealizowany przez artystkę film dokumentalny dotyczący tego samego tematu, co pozwala czytać Manic VR również w kontekście projektów wędrujących między mediami, przepisywanych na VR jako atrakcyjną, pozwalającą silniej się zanurzyć, platformę. Literackim przykładem takich działań byłoby Queerskins, początkowo e-powieść dostępna online, której części z czasem zostają stopniowo przearanżowane na doświadczenia VR, często zresztą nawet (będące dla mnie najlepszym punktem odniesienia) projekty MR, w których odbiorca doświadcza VR w specjalnie wykreowanej na potrzeby doświadczenia przestrzeni. 
tej VR-owskiej opowieści, ich funkcja - nieco inaczej niż u Hubera - polega raczej na wprowadzeniu odbiorcy w świat, w którym się znalazł (nie jest to raczej świat Kaliny, lecz jej rodzeństwa). To, czego dzięki interakcji w VR doświadcza widz, ma mu umożliwić wejście w skórę/głowę chorego, zrozumieć historię tych, którzy ją opowiadają. W strukturze całego doświadczenia jest więc wyraźnie zostawione sfunkcjonalizowane miejsce dla tego, kto słucha opowieści. Nie jest on tylko tym, kto ją podgląda, czy podsłuchuje, z założenia jest też tym, kto ma w jej obrębie działać. W tym wypadku - działać, by lepiej zrozumieć. Ja zaś chciałabym dopytać, czy możliwe są sytuacje, w których takie działanie odbiorcy mogłoby nieco bardziej dotyczyć samego świata przedstawionego, jeszcze silniej wiązać uczestnika doświadczenia z wirtualnym światem, pozwalać mu rzeczywiście być częścią fikcyjnej opowieści $^{36}$ (pamiętajmy, że praca Bertin ma charakter dokumentalny, nie tworzy świata przedstawionego w takim sensie jak klasyczne literackie czy filmowe opowieści, w których kontekście należałoby raczej rozpatrywać Data Urns). Chciałabym też zastanowić się, czy da się to osiągnąć nie tylko dzięki technologii, ale i za pomocą konkretnej struktury samej opowieści, może wręcz jej werbalnego składnika (skoro literatura to jedna z tych starszych ,technologii storytellingu”).

\section{Ten ważny partner dialogicznego monologu}

Żeby odpowiedzieć na pytanie, czy zmiana formuły literackiego (werbalnego) komponentu wpłynęłaby na immersję w przypadku interesującego mnie typu prac, chciałabym przyjrzeć się dziełu Hubera w kontekście kilku innych, bazujących na narracji mówionej, opowieści lokacyjnych, związanych z przypominaniem lub odtwarzaniem historii (będących immersyjnymi przestrzeniami pamięci zbiorowej lub korzystających z tejże jako tła dla osobistych, mniej lub bardziej fikcyjnych opowieści). Część $\mathrm{z}$ nich bazuje na wspomnianej strategii nakładania na aktualną przestrzeń odbioru tzw. dźwiękowego krajobrazu (soundscape) - tu konkretnie: przeszłości - pozwalając słuchaczom przenieść się w czasie (ich autorzy stosują więc prostsze niż Huber rozwiązanie). I w tym wypadku, choć podstawą immersji jest kluczowa dla narracji lokacyjnych obecność odbiorcy w danym miejscu, samo wrażenie przeniesienia w czasie kreowane jest przede wszystkim słowem (w większości przypadków również za pomocą dźwiękowego tła). Te wirtualne audioprzestrzenie przeszłości nakładane na teraźniejszą - mogą przybierać formułę: poligłosowych wspominków (jak w przypadku Trace Tori Rueb, określanego jako rodzaj dźwiękowego cmentarza, zbioru niewidzialnych audiopomników zmarłych ${ }^{37}$ ), jedno- lub wielogłosowych przewodników opowiadających historię danego miejsca (taki charakter ma słynne

36 Słowem - szukałabym odpowiednika sytuacji narracyjnej z przywoływanego Maginary, jego analogii w obszarze (niekoniecznie literackich czy czysto literackich) prac realizowanych jako eksplorowalne światy do zwiedzania, zanurzone w materialności immersyjne przestrzenie opowieści. 
34 North 118 West Jeremy'ego Highta, Jeffa Knowltona i Naomi Spellman, będące literackim przepracowaniem historii obszaru przylegającego do opuszczonego dworca w Los Angeles ${ }^{38}$ ) czy quasi-teatralnych, choć rozgrywających się wyłącznie w stymulowanej dźwiękiem wyobraźni odbiorcy, scenek odtwarzających przeszłość (np. 1831 RIOT!, swoisty przewodnik po Queen Square w Bristolu ${ }^{39}$ ). Nierzadko - co ważne w kontekście prowadzonych tu analiz - takie opowieści mają nie tylko charakter dokumentacyjny, zdarza się, że fikcyjną historię wpisują w - zdecydowanie mniej zmyślone - historyczne tło epoki, vide przypadek The Missing Voice Janet Cardiff, zanurzającego odbiorców zarówno w osiemnastowieczny East End, jak i we wspomnienia i paranoje bohaterki-narratorki.

Prace tej autorki uzmysławiaja, jak bardzo typowa dla takich narracji immersja bazuje na słowie. Dlatego w moim odczuciu audio-walki Cardiff klarownie wpisywały się w obszar (e-)literatury, będąc idealnym przykładem literackich narracji lokacyjnych, których charakterystyki dopominała się swego czasu Anna Nacher ${ }^{40}$. Jednak dla Valentiny Nisi były kanonicznym przykładem lokacyjnej multimodalnej narracji (traktowała je na równi z filmowymi projektami Interactive Cinema Research Group z MIT Media Lab czy teatralnymi realizacjami Rimini Protokoll) ${ }^{41}$, zaś Josephine Machon wspominała je już na drugiej stronie wnikliwego opracowania pt. Immersive Theatres ${ }^{42}$.

Przyczyny tego klasyfikacyjnego obłędu można, jak sądzę, upatrywać w strukturze proponowanych przez Cardiff „doświadczeń, strukturze - dodam od razu - pozornie bardzo bliskiej tej, po którą sięgnął Huber, lecz - literacko właśnie - jednak od niej odmiennej ${ }^{43}$. Z jednej strony odpowiednia forma werbalnej narracji (stanowiącej ich dominantę) pozwala je traktować jako teksty literackie. Z drugiej - równie mocno je konstytuujący lokacyjny charakter - wyrywa je z tej wąskiej klasyfikacji. Dodatkowo Cardiff w kolejnych pracach zaczyna uruchamiać inne jeszcze kanały i media komunikacji (nadal wpisanej w określony literackim pierwowzorem szablon opowieści): dynamiczny i statyczny obraz. Mniej będzie mnie tu jednak interesować wykorzystanie filmu (jak np. w projekcie The Telephone Call czy Alter Bahnhof Video Walk), fascynujące pod względem napięć teraźniejszość/przeszłość czy świat realny/świat opowieści. Dużo ciekawszym kontekstem dla dalszych analiz wydaje się bowiem praca Her Long Black Hair, proponująca wędrówkę po (współczesnym

38 Formalnie są to udramatyzowane (i odegrane przez aktorów) historie bazujące na materiałach archiwalnych.

39 Powstała w 2004 roku praca została współcześnie zremasterowana i od 2018 roku jest dostępna jako bezpłatna aplikacja korzystająca z GPS (co pokazuje aktualność takiej formy).

40 A. Nacher, Opowiadać (z) przestrzenia i sieciami - paradoksalne materializacje narracji lokacyjnych, „Teksty Drugie” 2015, nr 3, s. 78.

${ }^{41}$ V. Nisi, Location Aware Multimedia Stories: A Location Based View of Interactive Narrative, Lambert Academic Publishing, Erfurt 2011.

42 J. Machon, op. cit., s. 2.

43 A dodam tu jeszcze, że przywołane przed chwilą prace lokacyjne też w różnym stopniu wpisują odbiorcę w strukturę tekstu - pozwalają mu być domniemanym adresatem monologu lub po prostu świadkiem rozgrywających się scen. 
i dziewiętnastowiecznym) Central Parku, wędrówkę, w której oprócz nagrania audio wykorzystano udostępnione odbiorcom, jako materialne artefakty, zdjęcia, które stanowią dla narratora opowieści i jego słuchacza stały punkt odniesienia. W konsekwencji czysto literackiej strategii nawiązywania kontaktu z odbiorcą towarzyszy w tej realizacji materialny ślad owej relacji. Uczestnicy tego spaceru otrzymują bowiem plik zdjęć stanowiących nie tyle ilustrację, ile integralną część opowieści. I niby można by powiedzieć, że składowe doświadczenia (obecność w miejscu, werbalna narracja, skromna interakcja z przedmiotem) są tu zaprojektowane podobnie jak w przypadku Data Urns, a jednak samo doświadczenie ma zupełnie inny wymiar. Jest to skutkiem zupełnie innego sposobu poprowadzenia narracji, innej konstrukcji „ja" mówiącego i jego relacji z odbiorca ${ }^{44}$.

Symulując spotkanie ze swoim słuchaczem, bohaterka-narratorka zwraca się bezpośrednio do niego, regularnie prosi go, by odszukał odpowiednie zdjęcie i komentuje je, wiążąc fabułę z napięciami między rzeczywistościa, którą na nim widać (taką z przeszłości), a tą, w której znajduje się ona i jej odbiorca (szczególną rolę gra tu obecność na zdjęciach tajemniczej długowłosej kobiety) ${ }^{45}$. Tym samym opowieść nie tylko przenosi nas w fikcyjny świat (przeszłości), będący „nakładką” na naszą realną rzeczywistość, i krok po kroku po nim oprowadza. Stwarza zarazem bardzo konkretną iluzję współdoświadczania, zapraszając do wspólnego zwiedzania przestrzeni, rozmowy, w której jest dla nas miejsce ${ }^{46}$, choć w sumie w niej nie uczestniczymy (nie mamy możliwości wejść w interakcję z narratorką ${ }^{47}$ ). O ile w przypadku Data Urns odbiorca był podglądaczem (czy ,podsłuchiwaczem”), o tyle tu rzeczywiście wkracza w fikcyjny świat. Oczywiście umożliwia mu to wielopoziomowa struktura doświadczenia, jednak istota wskazywanej różnicy sprowadza się do innej struktury (słownej, literackiej) narracji: do napięć między intymną (ale jedynie podsłuchiwana), monologową narracją pierwszoosobową z listów (które jako bezpośrednio do nich adresowane, więc jakby

44 Taką strategię narracyjną spotkamy zresztą w większości prac Cardiff.

45 Strategię wzmacniania relacji i uwiarygodniania kontaktu ze słuchaczem poprzez ciąłe odwoływanie się do przestrzeni, w której się on znajduje, znajdziemy również w bardzo starych pracach Cardiff, np. w Bathroom Stories z 1991 roku (utworze będącym zresztą doskonałym przykładem tworzenia, przez werbalną narrację i dźwiękowy krajobraz, immersyjnej przestrzeni „uwspólnianych” wspomnień).

46 Pozwalałoby to czytać tę pracę również w duchu kognitywistycznie zorientowanej teorii odbioru narracji drugoosobowej, przez kategorię joint action (przez Magdalenę Rembowską-Płuciennik wiązaną raczej z innym niż apostroficzny typem narracji drugoosobowej). Por. M. Rembowska-Płuciennik, Second-person Narration: A New Mode of (Mis)Understanding the Other?, w: CultureCognition-Communication, ed. J. Hood, Peter Lang, Frankfurt am Main 2018, zwłaszcza s. 21-22.

47 Prace w rodzaju Call Cutta Rimini Protokoll, projektu określanego mianem teatru smartfonowego (mobile phone theatre), zakładają już taką interakcję. Ten postdramatyczny projekt teatralny bazuje na scenariuszu każdorazowo indywidualizowanym przez performera z call center. Jego uczestnicy-słuchacze w trakcie spaceru po Kalkucie z tym, odsłaniającym niezwykle osobistą wizję miasta, zdalnym przewodnikiem wielokrotnie zapraszani są do przełamania monologowej struktury i wejścia w prawdziwy dialog. Spektakl ten zdecydowanie daje się czytać jako próba tworzenia nakładanej na współczesną i dialogizującej z nią ,,wirtualnej przestrzeni pamięci”, niezwykle immersyjnej dla odbiorcy (odkrywającego na bieżąco, w dialogu z performerem, różnice między teraźniejszością a przeszłością). 
pisane w zakładającej kontakt z odbiorcą narracji drugoosobowej, mogliby odczytywać jedynie ich konkretni adresaci, nie przypadkowy słuchacz) a niepozwalającą wejść w interakcję, lecz zakładającą istnienie odbiorcy i bezpośredni z nim kontakt, narracją „paradoksalnie dialogicznego" monologu wypowiedzianego ${ }^{48}$.

W tej właśnie formie literackiej spotykamy formułę, w której odbiorca, tekstowe „ty”, staje się „elementem świata przedstawionego"49. Nieustannie obecne w tekście, wywoływane „metodą inwokacji” jest, jak doprecyzował Michał Głowiński:

czymś więcej niż drugim partnerem dialogu chociażby przez to, że jest ze swej natury niedookreślony, a przez swą ważną rolę, połączoną ze swoistą „niematerialnością”, prowokuje do ciagłego „dookreślania” w trakcie kontaktu czytelniczego. Czytelnik (traktowany tutaj nie jako konkretna osoba, ale jako postać określona czy wyznaczona przez tekst utworu) dokonuje swojego rodzaj substytucji, tzn. wchodzi w bezpośredni kontakt z narratorem, staje się tym „ty”, do którego narrator się zwraca ${ }^{50}$.

Podobnie dzieje się w przypadku analizowanej audionarracji. A przeglądanie rzeczywistych fotografii potwierdza i umacnia wpisaną w strukturę projektu rolę słuchacza. Można by powiedzieć: przecież gdyby nie było spotkania, nie trzymałby tych zdjęć w dłoni ${ }^{51}$. Interesująca mnie praca idzie krok dalej niż klasyczny literacki monolog wypowiedziany: wyprowadza owo miejsce dla „ty” poza przestrzeń tekstu, lokuje je w przestrzeni odbiorcy. Już nie czytelnik mocą wyobraźni bezcieleśnie siada obok narratora-bohatera opowieści, lecz tenże bezcielesny, lecz słyszalny bohater towarzyszy podmiotowi doświadczenia w jego działaniach w realnym świecie. W ten sposób fikcja miesza się z rzeczywistością (co niezwykle ciekawie wybrzmiewa właśnie w pracach grających ze wspomnieniami, z nakładaniem się na siebie płaszczyzn czasowych). Zaś motorem takiego „odfalsyfikowania” fikcyjnego świata jest w tym wypadku gest odbiorcy, gest rozgrywającego się w „tu i teraz” odbiorcy wejścia w miejsce pozostawione dla niego w tej ,jednostronnej rozmowie" ${ }^{2}$. Narracja stosowana przez Cardiff (również w innych jej pracach ${ }^{53}$ ) pełna jest zdań potwierdzających i umacniających ten kontakt, opowieść jest cały czas wypowiadana

48 Tak określił go przywołujący Winogradowską „dialogizację monologu” Michał Głowiński. Zob. M. Głowiński, Narracja jako monolog wypowiedziany, w: Z teorii i historii literatury, red. K. Budzyk, Ossolineum, Wrocław 1963, s. 236.

Ibidem, s. 238-239.

51 Pozwala to dostrzec, że analizowane tu opowieści idą krok dalej niż charakteryzowane przez Rembowską-Płuciennik jako typowe dla narracji diadycznej wymuszanie chwilowej (ale też - w porównaniu z przywoływanymi tu przypadkami - nadal jednak symbolicznej) ,autoreferencji” odbiorcy, utożsamianej przez badaczkę z ,przekroczeniem granic między światem tekstowym i realnym”. M. Rembowska-Płuciennik, O przechodzeniu na ty..., s. 253.

52 Ibidem, s. 236.

53 W The Missing Voice usłyszymy np. taki fragment: „There's a man signing out a book right now. I am going to follow him. Put the book back to where you found it. Let's go. You are in the Whitechapel Library". 
do tego kogoś, kim staje się albo po prostu jest słuchacz. Taka struktura narracji powoduje, że - inaczej niż w przypadku Data Urns - nie sposób mieć tu trudności $\mathrm{z}$ wejściem w rolę tego, który słucha (a nie podsłuchuje). Zwłaszcza że właśnie tak jak w klasycznych przykładach monologu wypowiedzianego, ów ktoś jest kreacja bardzo nieokreślona, zdefiniowaną jedynie przez swoje funkcje w tekście (w przypadku Her Long Black Hair: słuchanie i przeglądanie zdjęć). Audio-walki Cardiff (w tym i ten omawiany) cechuje też pewnego rodzaju despotyczność ich nadawców są przewodnikami, lecz nie znoszą sprzeciwu, nie dopuszczają innej możliwości niż to, że odbiorca podąży za ich (bardzo konkretnymi) wskazówkami (ale czy równie apodyktyczny nie jest - z definicji - każdy literacki narrator, bez którego słów nie rozegra się żadna opowieść, nie stanie się żaden świat przedstawiony?). Ten bardzo specyficzny pakt z odbiorcą wzmacniany jest, przynależącymi już nie do werbalnej warstwy opowieści, lecz do jej dźwiękowego tła, stanowiącego jej nieodłączny komponent, chwytami w rodzaju odtwarzania dźwięku kroków przewodnika, niezwykle sugestywnie narzucających tempo marszu (co bardzo ważne, kiedy trzeba zgrać długość wcześniej przygotowanego nagrania z trasą, którą - czysto teoretycznie - można by przecież pokonać $\mathrm{w}$ dowolnym tempie ${ }^{54}$ ).

Dla porównania warto tu przywołać jeszcze jeden projekt Rimini Protokoll: Situation Rooms, którego odbiorcy (kierowani obrazem wideo wyświetlanym na trzymanych w dłoniach ekranach) wcielali się w rolę kolejnych widocznych na filmie postaci i wędrowali po labiryntowej przestrzeni, podobnie jak w przywoływanym wcześniej Sanctuary. Tym razem jednak każdy z podmiotów opowiadających swoje życie (czy też oddających je do doświadczenia) zwracał się bezpośrednio do uczestników „,spektaklu”. W jednej ze scen konfrontowany ze swoim odbiciem widz słyszał: „Spójrz w lustro. Jestem hakerem. Teraz mam inne ciało, twoje"55. Stawiało go to w dość niewygodnej sytuacji: w każdej kolejnej części spektaklu narzucano mu inną rolę, zmuszano do błyskawicznego zmieniania „butów, w które wskakuje”, i „oczu, przez które patrzy" ${ }^{\prime 56}$. Można, oczywiście, dyskutować z sensownością czy funkcjonalnością takiego „teatru zniewolonego" ${ }^{57}$, jednak jedno trzeba o nim powiedzieć na pewno wpisuje widza (i jego obecność w świecie przedstawionym) w narracyjną strukturę opowieści. Zostawiając na boku podejmowane m.in. przez Zofię Smolarską kwestie

54 Zupełnie inaczej wygląda sytuacja w pracach posługujących się technologią GPS, które mogą uzależniać udostępnienie konkretnej części opowieści od przebywania odbiorcy w określonym miejscu. Prace Cardiff powstawały jednak, zanim technologia ta zaczęła być wykorzystywana w sztuce. Tym samym dowodzą one, że proponowane przez Highta szerokie rozumienie terminu „narracja lokacyjna" jest w pełni uzasadnione i że można tą kategorią opisywać nie tylko utwory wykorzystujące konkretną technologię czy jedynie nowomedialne (por. m.in. J. Hight, Locative Narrative, Literature and Form, w: Beyond the Screen, eds. J. Schäfer, P. Gendolla, Transcript, Bielefeld 2010, s. 323). Cytuję na podstawie dokumentacji dostępnych na stronach autorów.

Określenia używane przez Rimini Protokoll w kampanii promocyjnej.

57 Por. Z. Smolarska, Rimini Protokoll. Ślepe uliczki teatru partycypacyjnego, Instytut Teatralny im. Zbigniewa Raszewskiego, Akademia Teatralna im. Aleksandra Zelwerowicza, Warszawa 2017, s. $151-170$. 
dyskusyjnej wiarygodności samych przedstawień składających się na przywołany spektakl (lub pracę wideo, ang. multiplayer video piece - jak określili go sami twór$\mathrm{cy}^{58}$ ) czy naturalności wchodzenia w rolę mieszkańca zmaterializowanego wirtualnego świata opowieści, trzeba przyznać, że tekst przynajmniej daje taką możliwość. I choć zbieżny jest tematyką z przywoływanym tu wcześniej spektaklem Bretta Baileya czy VR-owym Limbo, tylko pozornie przypomina je też formalnie. Różnica kryjąca się w innej kreacji, wynikającej z literackiego komponentu struktury tekstu, jest tu fundamentalna. Każdy z przywołanych utworów zanurzał głębiej, mocniej, szybciej czy bardziej przekonująco niż klasyczna forma opowieści, właśnie dlatego, że - w różnym stopniu - zaprzęgał do aktu odbioru percepcję, zmysły i ciało odbiorcy. Jednak tylko niektóre wzmacniały jeszcze ten proces poprzez odpowiednią formę narracji. Dialogując z tytułami dwóch przywoływanych tu opracowań, mogłabym powiedzieć, iż właśnie w takim niedostrzeganiu mocy słowa i strategii wypracowanych przez jego sztukę tkwią ,ślepe uliczki (quasi-)literackich narracji immersyjnych”.

\section{Przenicowana literackość ucieleśnionych opowiadań scenicznych}

Choć znacząco przekracza to ramy tego szkicu, warto byłoby spojrzeć na analizowane tu narracje w szerszym jeszcze kontekście. Her Long Black Hair to oczywiście niejedyny tekst (kłopotliwie) literacki współtworzony przez fotografie (dość przypomnieć np. prozę Winfrieda Georga Sebalda, Randoma Riggsa czy Jacka Dehnela). Wyjątkowość tej pracy nie do końca polega też wyłącznie na wprzęgnięciu w jej poetykę tego, co moglibyśmy określić mianem pogłębionych figur czytelniczych gestów, na wzmocnieniu relacji odbiorcy ze światem przedstawionym właśnie poprzez symulację kontaktu z narratorką-bohaterką, kreowanie poczucia współobecności i, w konsekwencji, steatralizowanie tym samym całego doświadczenia. Wprzęgnięcie w strukturę opowieści realnych przedmiotów (zdjęć), kreowanie przy ich pomocy rodzaju fikcyjnej, lecz materialnej, nakładki na rzeczywistość mogłoby poprowadzić ku dalszym rozważaniom o teatralnej proweniencji: ku analizie roli przedmiotu na takiej „literackiej scenie” czy nawet ogólnej refleksji o scenografii takich rzeczywistych fikcyjnych światów ${ }^{59}$.

Te zagadnienia mogłyby podyktować porządek dalszych rozważań: przyjrzenie się wykorzystującym narrację audio (oraz inne formy tekstu) pracom, w których jeszcze większą rolę odgrywają symulakryczne, mimetyczne w stosunku do nieistniejących powieściowych światów, przedmioty czy przestrzenie oraz działania odbiorców, których skutki przynależą do obu ontologicznych porządków (świata

58 Opis ze strony autorów (www.rimini-protokoll.de [dostęp: 31.01.2020]).

59 Innym jeszcze kontekstem, którego omówienie przekracza ramy tego opracowania, jest kwestia przemian w teatrze, prowadzących do przewartościowania kategorii sceny i przestrzeni scenicznej (por. np. L.G. Nibbelink, Nomadic Theatre. Mobilizing Theory and Practice on the European Stage, Bloomsbury, New York 2019). 
rzeczywistego, właściwego „tu i teraz” odbiorców oraz, nakładającego się nań, jakiegoś ,,tam i wtedy” świata wirtualnego). Punktem wyjścia mogłyby być prace Caitlin Fisher, zwłaszcza stworzone wespół z Tonym Vieirą Home/Mother/Heaven: tekst nie tylko ewidentnie lokacyjny (żądający od odbiorców odbioru narracji w bardzo określonej przestrzeni) $^{60}$, lecz również taki, w którym (w znacznie większym stopniu niż w pracach dotąd przywołanych) interakcja z realnymi przedmiotami staje się kluczem do poznania opowieści, same zaś artefakty - jej scenograficznym śladem ${ }^{61}$. Od przepisującej historię pracy Fisher można by przejść do projektów, które choć nie zawsze sięgają po nowe technologie, tworzą (czy odtwarzają w materii) całe wirtualne światy. Tu jako ciekawy przykład widziałabym Turnton Docklands grupy Time’s Up (której działania znów otwierałyby dyskusję o kontekstach teatralnych ${ }^{62}$ ), analizowane w świetle koncepcji physical narratives (tak artyści nazywają tworzone przez siebie od lat 90. XX w., zaklęte w eksplorowalnych przestrzeniach opowieści) ${ }^{63}$. Przywołana przeze mnie instalacja (jako futurystyczna dystopia służąca retrospektywnej ocenie przeszłości i w związku z tym, podobnie jak Data Urns, spajająca trzy w sumie przestrzenie czasowe) to przykład VR bez VR, świata-środowiska ${ }^{64}$, w który

60 Mam tu na myśli przede wszystkim pierwotną wersję pracy, która była częścią wystawy Land|Slide Possible Futures z 2013 roku. Choć późniejsze eksperymenty z oderwaniem tego ewidentnie placebound projektu od rdzennej lokacji i próbą symbolicznego odtwarzania jego realnej przestrzeni, która w samej pracy też była swoistą rekonstrukcją przestrzeni historycznej (np. wystawienie tej pracy w ramach festiwalu e-literackiego podczas konferencji ELO w Bergen w 2015 roku), byłyby tu ciekawym kontekstem rozważań.

61 Podobny charakter ma praca Circle, niezwiązana jednak (jak przywołany projekt) z większą przestrzenią, w którą wkracza interaktor, lecz ograniczona do walizeczki, w której ukryte są odsyłające do wspomnień przedmioty. Prototyp pracy miał z kolei formę rozkładanego teatrzyku, w którym zamiast przedmiotów pojawiały się papierowe kody QR. Zmiana platformy, umożliwiająca udoskonalenie projektu i nadanie mu formy, w której odbiorca wchodzi w interakcję z przedmiotem (a nie jego symbolem), wydaje się ważnym i świadomym krokiem autorki na drodze eksplorowania tego właśnie typu immersji, a mowa tu przecież o artystce od lat już zajmującej się literackimi eksperymentami z AR (dość przywołać nagradzaną Andromedę, Requiem czy 200 Castles). Fisher eksperymentowała też z literaturą w VR (jej literackie opowieści VR wyprzedzają głośne ostatnio i nagradzane eksperymenty Mez Breeze) - przykładem jest włączony do trzeciego tomu Electronic Literature Collection utwór Everyone at this Party Is Dead z cyklu Cardamon of the Dead, który proponując „psychogeograficzny pałac pamięci eksplorowalny dla użytkownika przy pomocy interfejsu VR" (Oculus Rift), byłby tu z pewnością kolejnym ciekawym punktem odniesienia; http://collection. eliterature.org/3/work.html?work=everyone-at-this-party-is-dead (dostęp: 20.12.2019).

62 Dla tego bowiem kolektywu kreowane przez nich ,środowiska” są też, a może wręcz przede wszystkim, miejscem prowadzenia warsztatów, co pozwalałoby widzieć je w kontekście teatru partycypacyjnego.

63 Warto jednak pamiętać, że temat pamięci w literackich pracach VR przepracowywany był jeszcze w poprzednim tysiącleciu - przykładem wielokrotnie opisywany projekt Screen. Por. np. M. Górska-Olesińska, Tekstowe instrumenty do gier z pamięcia, „,Kultura Popularna” 2010, nr 3-4.

64 To z kolei kazałoby przywołać przepracowywane już kategorie tekstu-środowiska, wiersza-środowiska itp. Na potencjalną teatralność takich instalacji zwracała uwagę w autoanalizach swoich wielkoformatowych książek Alison Knowles. Zob. A. Knowles, On the Book of Bean: The First Guided Tour through the Book of Bean, w: A Book of the Book, eds. J. Rothenberg, S. Clay, Granary Books, New York 2000. 
odbiorca zanurza się - niczym w teatrze partycypacyjnym czy immersyjnym - na drodze odkryć własnych i konfrontacji z realnymi sytuacjami, choć świat ten jest nierzeczywisty, fikcyjny, wirtualny. Nieistniejący, choć namacalny.

„Pożyczając” od Madsa Haahra wygodną metaforę, można by powiedzieć, że takie realne, symulakryczne (bo mimetyczne w stosunku do nieistniejących światów) środowiska to ,przenicowane holodeki”. Analizując immersyjne środowiska interaktywne, badacz ten zaznaczał, że choć dominującą tendencją jest umieszczanie widzów „»wewnątrz« symulacji”, spotyka się też prace wywracające ten układ do góry nogami, w przypadku których ,elementy narracji są lokowane w »fizycznej przestrzeni« zamieszkiwanej przez widzów"65. Te ostatnie (za których egzemplifikację uznał lokacyjne gry rzeczywistości rozszerzonej) określił właśnie metaforycznie mianem ,„przenicowanych holodeków" (ang. everted holodeck). Analizowane przeze mnie w tym szkicu prace w podobny sposób, na bardzo wielu poziomach, odwracają, ,przenicowują”, wywracają do góry nogami klasyczne strategie i ujęcia (m.in. koncepcję literackości).

Pokazywałam, że taki „wywrócony na drugą stronę” monolog wypowiedziany może zakorzeniać w świecie realnym relację łączącą czytelnika i narratora. Sugerowane tu pogłębienie badań nad włączaniem realnych przedmiotów i działań odbiorców „w przestrzeni tekstu” w obręb zakładanych strategii odbioru i procesów sensotwórczych czy namysł nad teatralizacją takich opowieści i wymiarem, który roboczo określiłam ,scenografią” fikcyjnych światów, mogłyby doprowadzić do przypomnienia (jako pomocnych w analizach) innych jeszcze klasycznych ujęć teoretycznoliterackich. Użyteczne wydawałoby mi się tu np. sięgnięcie do bardzo leciwych (jeszcze dziewiętnastowiecznych) rozważań teoretycznoliterackich, by przywołać zaproponowaną przez Ottona Ludwiga (notabene autora nie tylko prozy, ale i dramatów) kategorię opowiadania scenicznego (niem. szenische Erzählung), przez Franza Stanzela przyswojoną teorii literatury jako prezentacja sceniczna (niem. szenische Darstellung). Ten ostatni podkreślał, że w takiej formie opowiadania „czytelnik staje się naocznym świadkiem biegu wydarzeń z pomocą wyobraźni umieszczając siebie w postaci obserwującego"66. W przypadku analizowanych przeze mnie prac do głosu dochodzi nie tyle wyobraźnia, ile zmysły, dzięki którym „czytelnik” (odbiorca) postrzega świat, bo „,naoczność” jest w tym wypadku realna. W konsekwencji - o ile w ,czystej” literaturze - jak podkreślał Stanzel - muszą pojawić się określenia pozwalające czytelnikowi (wyobrażającemu sobie, ,że jest obecny w miejscu rozgrywających się wydarzeń" ${ }^{67}$ ) dokładniej ulokować się w czasie i przestrzeni, o tyle odbiorca charakteryzowanych przeze mnie immersyjnych narracji, fizycznie i dosłownie zanurzony w świat opowieści, orientuje się właśnie „naocznie”, bo dosłownie eksploruje fikcyjny świat (czuje go, a nie

65 M. Haahr, Everting the Holodeck. Games and Storytelling in Physical Space, w: Interactive Digital Narrative. History, Theory and Practice, eds. H. Koenitz et al., Routledge, New York 2015, s. 211.

66 F. Stanzel, Typowe formy powieści, w: Teorie form narracyjnych w niemieckim kręgu językowym. Antologia, oprac. R. Handke, Wydawnictwo Literackie, Kraków 1980, s. 250.

67 Ibidem. 
przeczuwa ${ }^{68}$. Świat, który wcześniej musiał być - na potrzeby doświadczenia - skonstruowany, nie ze słów, lecz z materii. Z tego właśnie powodu powiedziałabym, że jego literackość jest na swój sposób ,przenicowana”.

Stanzel upatrywał mocy prezentacji scenicznej w tym, jak silnie oddziałuje ona na czytelnika, budząc w nim współczucie, grozę, napięcie czy niepewnośćc ${ }^{6}$. Inspirujący go Ludwig tłumaczył to tym, iż w tej formie (inaczej niż w narracji relacjonującej) „środkiem komunikacji” nie jest „,tylko ucho”, że owo „ucho do pewnego stopnia komunikuje się z okiem”, bo „czytelnik nie doświadcza rzeczy w sposób abstrakcyjny, ale umieszcza ją przed swoim wewnętrznym okiem"70. W przypadku quasi-literackich narracji immersyjnych, o których tu pisałam, już w ogóle nie możemy mówić o postrzeganiu abstrakcyjnym - odbiorca umieszcza rzeczy przed swoimi zmysłami, przed całym swoim ciałem, i to w swoim ,tu i teraz”. Dlatego może należałoby takie teksty nazwać ucieleśnionymi, przenicowanymi opowieściami scenicznymi. Wykraczającymi poza ramy literatury, teatru czy sztuki (nowomedialnej?), wymagającymi do ich opisania równie jak one przenicowanej i patchworkowej metodologii, czerpiącej narzędzia z różnych obszarów (co przecież nie jest żadną nowością dla badaczy współczesnych czy dawnych tekstów „nieczystych”, „zmąconych”). Przywoływana Anna Krajewska, podobnie jak ja przecząca łatwości oddzielania przestrzeni literackości i teatralności „czystej” (w szkicu Humanistyka performatywna), analizując obszary ich twórczego nakładania się, stwierdzała:

Literatura znosi przedział między językiem a światem. Język sztuki jest w swej funkcji performatywny w znaczeniu powoływania do istnienia rzeczywistości, która nie ma żadnego pierwotnego, uprzedniego odniesienia, przedustanowienia. Czyni to w procesie opisywania hipotetycznego świata, który równocześnie w tym dyskursie powołuje do istnienia. Buduje dyskurs performatywny wytwarzający światy, których wcześniej nie było (ale pewności, czy gdzieś nie egzystują, wcale nie mamy). Między językiem a światem nie istnieje zatem przepaść, język równocześnie wytwarza świat i jest jego jedynym odniesieniem ${ }^{71}$.

W przypadku tekstów, o których tu pisałam, nawet jeśli dostrzegamy w nich wyraźną literacką dominantę, nawet jeśli motorem ich działania jest przede wszystkim słowo (a tak przecież jest zarówno w wypadku pracy Hubera, jak i audio-walków Cardiff), inaczej należałoby mówić o performatywności, bo język nie jest już ,jedynym

68 Jednocześnie w narracji w formie prezentacji scenicznej, podobnie jak w przypadku opisywanych tu instalacji audio lub doświadczeń VR czy MR, czas doświadczenia zrównuje się z czasem opowieści. A przypomnę, że jednym z najbardziej klasycznych zabiegów literackich pozwalających unaocznić opowieść jest właśnie zastosowanie praesens historicum. Z kolei w cinematic VR sama specyfika obrazu filmowego lokuje widza w „tu i teraz”, zaś w przypadku instalacji MR fizyczna obecność odbiorcy w świecie opowieści ewokuje poczucie teraźniejszości.

69 F. Stanzel, op. cit., s. 250.

70 O. Ludwig, Formen der Erzählung, w: Realismus und Gründerzeit. Band 2: Manifeste und Dokumente zur deutschen Literatur 1884-1880, eds. M. Bucher et al., Springer, Stuttgart 1975, s. 379 [przeł. M. Wąsik].

71 A. Krajewska, op. cit., s. 56. 
odniesieniem” zmaterializowanych i „przenicowanych” światów. Niezwykle wyraźnie widać to w pracach w rodzaju instalacji Time's Up - np. integralną częścią Turnton Docklands jest papierowa (!) gazeta z przyszłości (wydana w 2047 roku), której lektura pozwala zrozumieć poszczególne części eksplorowanej przestrzeni.

Czas dodać, że przywołane na wstępie Draw me Close składa się z dwóch części. Nie wspominałam o tym dotąd, bo może trafniej byłoby powiedzieć, że widz uczestniczy w nim dwukrotnie. Kiedy zdejmuje gogle VR, ma możliwość obejrzeć cały spektakl raz jeszcze, zobaczyć całą tę sytuację z dystansu, „przenicowaną”, poczuć, jak różna jest opowieść, której jest się podmiotem, od tej, którą jedynie oglądamy. Opuszcza ramy widowni dopiero, gdy kolejny widz zakończy interakcję i będzie chciał zająć jego miejsce. Oczywiście doświadczenie takie doskonale ujmuje kluczowy dla tego artykułu problem, jednak sprytnie obrazuje jeszcze jedną kwestię. Moje czytelnicze, intelektualne i metodologiczne wędrówki w obszary (pozornie) bardzo dalekie od literatury i literackości pozwoliły mi spojrzeć z dystansu, a takie spojrzenie (nie tylko w spektaklu Tannahilla), oferując inną perspektywę, ułatwia czasem dostrzeżenie pewnych kwestii. Mnie z pewnością uzmysłowiło, jak użyteczne mogą być bardzo stare narzędzia i metodologie literaturoznawcze w kontekście nowych, niewpisujących się w klasyczne podziały sztuk, narracji. Pod warunkiem, że odpowiednio je ,przenicujemy”.

\section{Bibliografia}

Borsuk A., The Book, The MIT Press, Cambridge 2019.

Bouchardon S., Figures of Gestural Manipulation in Digital Fictions, w: Analyzing Digital Fiction, eds. A. Bell, A. Ensslin, H.K. Rustad, Routledge, New York 2014.

Bouchardon S., Mind the Gap! 10 Gaps for Digital Literature?, „Electronic Book Review” 2019, May 5, http://electronicbookreview.com/essay/mind-the-gap-10-gaps-for-digitalliterature/ (dostęp: 1.06.2019).

Bouchardon S., Heckman D., Digital Manipulability and Digital Literature, „Electronic Book Review” 2012, August 5, https://electronicbookreview.com/essay/digital-manipulability-and-digital-literature/ (dostęp: 1.02.2020).

Candoni C., Sanctuary, Brett Bailey du côté des réfugiés, 19.06.2017, https://toutelaculture. com/spectacles/sanctuary-brett-bailey-du-cote-des-refugies/ (dostęp: 10.01.2020).

Dixon S., A History of Virtual Reality in Performance, „International Journal of Performance Arts and Digital Media" 2006, vol. 2, nr 1.

Głowiński M., Narracja jako monolog wypowiedziany, w: Z teorii i historii literatury, red. K. Budzyk, Ossolineum, Wrocław 1963.

Górska-Olesińska M., Tekstowe instrumenty do gier z pamięcia, „Kultura Popularna” 2010, nr 3-4.

Haahr M., Everting the Holodeck: Games and Storytelling in Physical Space, w: Interactive Digital Narrative: History, Theory and Practice, eds. H. Koenitz et al., Routledge, New York 2015 . 
Hight J., Locative Narrative, Literature and Form, w: Beyond the Screen, eds. J. Schäfer, P. Gendolla, Transcript, Bielefeld 2010.

Knowles A., On the Book of Bean: The First Guided Tour through the Book of Bean, w: A Book of the Book, eds. J. Rothenberg, S. Clay, Granary Books, New York 2000.

Krajewska A., Humanistyka performatywna, „Przestrzenie Teorii” 2018, nr 29.

Ludwig O., Formen der Erzählung, w: Realismus und Gründerzeit. Band 2: Manifeste und Dokumente zur deutschen Literatur 1884-1880, eds. M. Bucher et al., Springer, Stuttgart 1975.

Machon J., Immersive Theatres: Intimacy and Immediacy in Contemporary Performance, Palgrave Macmillan, London 2013.

Marques D., Reading Digits: Haptic Reading Processes in the Experience of Digital Literary Works, Coimbra 2018, praca doktorska opublikowana online: https://estudogeral.sib.uc.pt/ handle/10316/81171 (dostęp: 10.01.2020).

Milligan C.A., The Page Is a Touchscreen: Haptic Narratives and "Novel” Media, „Paradoxa” 2017, nr 29 (Small Screen Fictions, ed. A. Ensslin, L. Swanstrom, P. Frelik).

Murray J.H., Hamlet on the Holodeck: The Future of Narrative in Cyberspace. Updated Edition, The MIT Press, London 2016.

Nacher A., Opowiadać (z) przestrzeniq i sieciami - paradoksalne materializacje narracji lokacyjnych, „Teksty Drugie” 2015, nr 3.

Nibbelink L.G., Nomadic Theatre: Mobilizing Theory and Practice on the European Stage, Bloomsbury, New York 2019.

Nisi V., Location Aware Multimedia Stories: A Location Based View of Interactive Narrative, Lambert Academic Publishing, Erfurt 2011.

Nora P., Między pamięcia i historią: Les lieux de Mémoire, w: Tytuł Roboczy: Archiwum\#2, red. M. Ziółkowska, A. Leśniak, Muzeum Sztuki w Łodzi, Łódź 2009.

Przybyszewska A., Po(d)żeranie tekstu. Wstęp do rozważań o czytaniu kinetycznym, w: e-polonistyka 3, red. A. Dziak, A. Kopacz, Wydawnictwo KUL, Lublin 2016.

Reaney M., Virtual Reality and the Theatre: Immersion in Virtual Worlds, „Digital Creativity” 1999, vol. 10, nr 3.

Rembowska-Płuciennik M., O przechodzeniu na ty... Narracja diadyczna wśród literackich reprezentacji świadomości bohatera, w: (W) sieci modernizmu. Historia literatury - poetyka - krytyka. Prace ofiarowane Włodzimierzowi Boleckiemu, red. A. Kluba, M. Rembowska-Płuciennik, IBL PAN, Warszawa 2017.

Rembowska-Płuciennik M., Second-person Narration: A New Mode of (Mis)Understanding the Other?, w: Culture - Cognition - Communication, ed. J. Hood, Peter Lang, Frankfurt am Main 2018.

Ryan M.-L., Narrative as Virtual Reality: Immersion and Interactivity in Literature and Electronic Media, The Johns Hopkins University Press, Baltimore-London 2001.

Ryan M.-L., Narrative as Virtual Reality 2: Revisiting Immersion and Interactivity in Literature and Electronic Media, The Johns Hopkins University Press, Baltimore 2015.

Salter A., What Is Your Quest? From Adventure Games to Interactive Books, University of Iowa Press, Iowa City 2014.

Simanowski R., What Is and to What End Do We Read Digital Literature?, w: Literary Art in Digital Performance: Case Studies in New Media Art and Criticism, ed. F.J. Ricardo, Continuum, New York-London 2009. 
Smolarska Z., Rimini Protokoll. Ślepe uliczki teatru partycypacyjnego, Instytut Teatralny im. Zbigniewa Raszewskiego, Akademia Teatralna im. Aleksandra Zelwerowicza, Warszawa 2017.

Stanzel F., Typowe formy powieści, w: Teorie form narracyjnych w niemieckim kręgu językowym. Antologia, oprac. R. Handke, Wydawnictwo Literackie, Kraków 1980.

Strickland S., Lawson C., Vniverse, w: New Media Poetics: Contexts, Technotexts, and Theories, eds. A. Morris, T. Swiss, The MIT Press, Cambridge 2006, s. 177.

Szczęsna E., Cyfrowa semiopoetyka, IBL PAN, Warszawa 2018.

The Videofag Book, ed. W. Ellis, J. Tannahill, Book*hug, Toronto 2018.

Ziomek J., Powinowactwa literatury: studia i szkice, PWN, Warszawa 1980. 